\title{
SOUTH AFRICAN LABOUR LAW AMENDMENTS: POSITIVE ASPECTS AND UNINTENDED CONSEQUENCES FOR SKILLS DEVELOPMENT
}

\author{
Sylvia Hammond ${ }^{*}$
}

South Africa's developing country status is well known, as is the specific challenge to redress the legacy of a racially discriminatory education system. Although youth unemployment is an international concern, recent research for Department of Higher Education and Training found 3 million young South Africans not in employment, education, or training (NEETS). Persistent elevated levels of unemployment and underemployment hamper poverty reduction. Skills development is a key policy instrument of redress. However, access to workplace-based learning and experience is essential for achieving the occupational skills and qualifications that provide access to permanent employment. This paper utilises the Learnership structure to examine positive effects and possible unintended consequences of the recent amendments to the Labour Relations, Basic Conditions of Employment and Employment Equity Acts, and the Temporary Employment Services Act, upon the implementation of skills development. Statutory structures created by the Skills Development, and Skills Development Levies Acts, and the National Qualifications Framework Act are described, as is the centrality of workplace-based learning to the achievement of qualifications approved by the Quality Council for Trades and Occupations, and registered with the South African Qualifications Authority against levels of the National Qualifications Framework. The conclusion summarises conflicting definitions of employment and learning and makes proposals for enhancement of skills development outcomes.

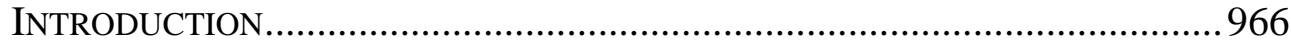

I. THE SKILLS DEVELOPMENT FUNDING MODEL ........................................967 II. NATIONAL STRATEGY AND DisCRETIONARY GRANT FUNDED

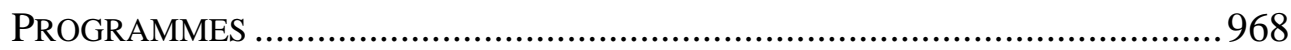

\footnotetext{
${ }^{*}$ PhD Candidate, University of Cape Town. M.Phil. (Advanced Labour Law) Cape Town. Research interest: The implementation of skills development in the context of the changing world of work. The relationship of skills development law and the associated laws and regulation to labour law and the employment relationship.

Under supervision of:

Professor Paul Bowen, Lecturer: Engineering and Built Environment, Construction Economics and Management Faculty, University of Cape Town.

Professor Keith Cattell, Head of Department: Engineering and Built Environment, Construction Economics and Management Faculty, University of Cape Town.

Professor Evance Kalula, Director: International Academic Programmes Office and Director Confucius Institute, University of Cape Town. President: International Labour and Employment Relations Association.
} 


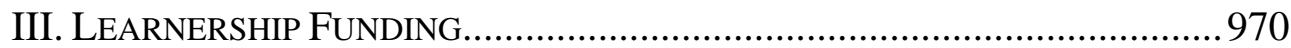

IV. LEARNERSHIPS AND TWO FORMS OF EMPLOYMENT CONTRACT ............971

V. THE SOURCE OF TWO FORMS OF EMPLOYMENT CONTRACT....................972

VI. DOCUMENTARY EVIDENCE SUPPORTING THE 18(2) EMPLOYMENT

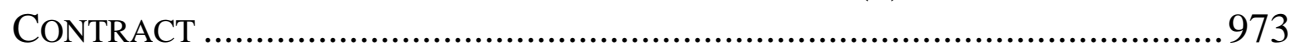

VII. EXAMPLES OF LEARNERSHIPS IN PRACTICE ........................................974

VIII. COUNTER ARGUMENTS TO AN 18(2) EMPLOYEE STATUS .....................975

IX. EMPLOYER RESISTANCE TO A FORMAL EMPLOYMENT RELATIONSHIP.. 975

X. EMPLOYMENT EQUITY ACT AND UNFAIR DISCRIMINATION ...................977

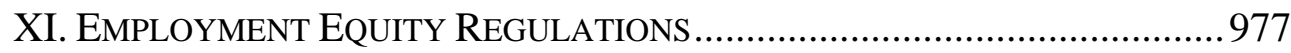

XII. EMPLOYMENT EQUITY CODE OF GOOD PRACTICE ...............................978

XIII. EMPLOYMENT EQUITY COMPLIANCE.............................................979

XIV. PAYMENT TO PROCURE TRAINING...................................................980

XV. TEMPORARY EMPLOYMENT SERVICES AND LEARNERSHIPS ................980

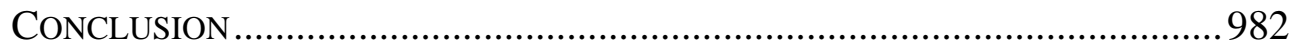

\section{INTRODUCTION}

Skills development arguably sits uneasily within labour law; the Skills Development Act (SDA) ${ }^{1}$ and the Employment Equity Act (EEA) $)^{2}$ may be described as contributing to transformation and redress for past discrimination and exclusion from education, qualifications and life chances. However, both the SDA and EEA are included in the definition of "employment law" in the Labour Relations Act (LRA). In an historical context, South Africa is moving from segregated exclusion from access to education and training to a vision of universal access to education from Early Childhood Development (ECD) to funded access as far as tertiary education and training, whether academic, vocational, or technical. ${ }^{4}$ Both the SDA and EEA are applicable to adults in South African workplaces, from youthful "born-free" entrants to older work-experienced adults without formal qualifications - or even basic literacy and numeracy. Together the SDA and EEA support the removal of barriers to individual performance and enable advancement to formally recognised occupational qualifications and career advancement. This paper therefore examines how the implementation of skills development may be positively or adversely affected by the recent comprehensive labour law amendments. To a limited

\footnotetext{
${ }^{1}$ RSA, The Skills Development Act 97 of 1998, GoN 1400 (Pretoria: GG 19420 1998).

2 RSA, Employment Equity Act 55 of 1998, GoN 1323 (Pretoria: GG No. 19370 1998).

${ }^{3}$ RSA, The Labour Relations Act 66 of 1995, GoN 1877 (Pretoria: GG No. 16861 1995). Section 213.

${ }^{4}$ The National Student Aid Fund (NSFAS) is the South African Government national student loan and bursary fund. Available at http://www.nsfas.org.za/ (last visited July 30, 2015).
} 


\section{SOUTH AFRICAN LABOUR LAW AMENDMENTS 967}

extent, this paper provides an update to a chapter by Paul Benjamin, in which he identified: “... the proliferation of laws with different, and at times conflicting, objectives and overlapping sets of rights and obligations undermines rather than promotes the achievement of overall goals." 5

For context, the skills development funding model, statutory structures, and implementation mechanisms are described. The unique South African formulation of a "Learnership" for acquisition of occupational qualifications is then utilised to examine how the amendments to the: LRA, ${ }^{6}$ the Basic Conditions of Employment Act (BCEA), ${ }^{7}$ and the EEA may benefit-or hamper-skills development. The centrality of the workplace and employment for Learnership implementation and qualification acquisition is explained, thereby raising: inconsistencies in interpretation and application between statutes; potential implications of the recent cases "deeming" Temporary Employment Service (TES) placements in excess of three months as "employees" of clients; and potential adverse industrial relations implications of the requirements for equal pay for work of equal value. The approach is multi-disciplinary and aims to examine how the implementation of these statutes manifests at the workplace from the perspective of a generalist human resource practitioner. Only brief reference is made to the taxation implications of skills development implementation and of Broadbased Black Economic Empowerment (B-BBEE). Finally, the concluding section advances an argument for greater alignment of statutory definitions, and a clearer definition of the Learnership employment relationship for previously unemployed learners.

\section{The SkiLls Development Funding Model}

Skills development falls under the Department of Higher Education and Training (DHET), ${ }^{8}$ and the structures and processes are part of a differentiated, articulated post-school education and training landscape. ${ }^{9}$ The three main labour law statutes, namely: the LRA, BCEA and EEA discussed in this paper fall under the Department of Labour

\footnotetext{
${ }^{5}$ Benjamin, Different Routes to Equality and Empowerment, EQUALITY IN THE WORKPLACE REFLECTION FROM SOUTH AFRICA AND BEYOND 119 (Ockert Dupper \& Christoph Garbers eds., 2009).

${ }^{6}$ RSA, The Labour Relations Act 66 of 1995.

${ }^{7}$ RSA, Basic Conditions of Employment Act 75 of 1997, GoN 1631 (Pretoria: GG No. 18491 1997).

${ }^{8}$ RSA, Tranfer of Administration and Powers and Functions Entrusted by Legislation to Certain Cabinet Members in Terms of Section 97 of the Constitution, Proclamation 44 (Pretoria: GG 32367 2009).

${ }^{9}$ DHET, White Paper for Post-School Education and Training: Building an Expanded, Effective and Integrated Post-School Education System, Gon No 11 (Pretoria: GG. 37229 2014).
} 
(DoL). ${ }^{10}$ The skills funding model comprises a Skills Development Levy (SDL) of one percent of payroll paid monthly to the South African Revenue Service by all employers with an annual payroll in excess of R500,000 per annum. ${ }^{11}$ There are a number of exclusions from the calculation of remuneration, notably for this paper, the amount payable to a "learner" contracted on a Learnership, who was previously unemployed. ${ }^{12}$ Twenty percent of the SDL goes towards a National Skills Fund (NSF) for national priority interventions. ${ }^{13}$ The remaining eighty percent of SDL is directed to twenty one Sector Education and Training Authorities (SETAs). ${ }^{14}$

The SETAs are entitled to retain 11.5 percent of SDL received for administration, 5 percent to be contributed to the Quality Council for Trades and Occupations (QCTO), and to disburse twenty percent back as mandatory grants to participating and compliant employers in their sector. ${ }^{15}$ Thereafter remaining funds are available for disbursement as discretionary grant funding to employers, who participate in identified priority and PIVOTAL ${ }^{16}$ programmes. As the following section will demonstrate the funds available to a participating, employer may potentially exceed what was paid in SDL. How these strategic priorities are identified and the types of skills development programmes funded by discretionary grants is now described.

\section{NATIONAL STRATEGY AND DiSCRETIONARY GRANT FUNDED PROGRAMMES}

\section{The National Human Resource Development Strategy (NHRDSSA) ${ }^{17}$}

\footnotetext{
${ }^{10}$ Other statutes mentioned briefly are: RSA, Employment Tax Incentive Act 26 of 2013, GoN. 1032 (Pretoria: GG No. 37185 2013). Issued by National Treasury, and the RSA, Broad-Based Black Economic Empowerment Act 53 of 2003, GoN 17 (Pretoria: GG 25899 2003). Issued by the Department of Trade and Industry (dti).

${ }^{11}$ As the remuneration of managers, owners or directors in included in the calculation of R500,000 in practice over a range of sectors this threshold is reached once companies have a regular employment complement of approximately 12 employees. National and Provincial government, public benefit organisations, and municipalities "granted an exemption are exempted from payment of the SDL".

${ }^{12}$ RSA, Skills Development Levies Act 9 of 1999, GoN 516 (Pretoria: GG No. 19984 1999). Section 3(5)(d).

${ }^{13}$ RSA, The Skills Development Act 97 of 1998. Sections 27-29.

${ }^{14}$ RSA, Skills Development Levies Act 9 of 1999. Section 8.

${ }^{15}$ Employers who prepare annual Skills and PIVOTAL plans and annual Training reports and annual reports on PIVOTAL programmes implemented, which are submitted by the gazetted date, currently by end April. The SETA Grant Regulations regarding Monies Received by SETA \& Related Matters No. R.990 GG No. 35940 and Amendment Notice to Gon R.990 Published in GG No. 35940 of December 3, 2012 of July 15, 2013.

${ }^{16}$ PIVOTAL is an acronym for professional vocational technical and academic programmes, which lead to a qualification or part-qualification registered by SAQA. Available at http://www.merseta.org.za/Portals/0/WHAT\%20IS\%20A\%20PIVOTAL\%20PROGRAMME.pdf (last visited July 30, 2015).

${ }^{17}$ DHET, Human Resource Development Strategy for South Africa HRD-SA 2010-2030, (Pretoria 2009).
} 


\section{SOUTH AFRICAN LABOUR LAW AMENDMENTS 969}

sets overall national education and development priorities, and the National Integrated Human Resource Development Plan has been aligned to national economic strategic goals. ${ }^{18}$ The skills development subset is itemised in the National Skills Development Strategy (NSDS) ${ }^{19}$. The NSDS objectives and indicators are cascaded down by the DHET Director General into an annual Service Level Agreement with each SETA. ${ }^{20}$ The discretionary funding is utilised to encourage employers to participate in the programmes that assist the SETA in meeting the performance targets agreed with the DHET. Depending on the individual sectoral requirements, the usual priority programmes receiving discretionary funding are: Adult Education and Training (literacy and numeracy), Technical Vocational Education and Training (TVET) (certificate) programmes, artisan listed trade qualifications (apprenticeships) $^{21}$, practical work experience required for the achievement of a qualification (in-service training), post-graduate internships, bursaries and Learnerships.

Funding levels vary year on year depending upon identified priorities and each sector, and the various programmes attracts differing levels of discretionary grant funding. Examples of funding levels are: R2,000 per learner per AET programme (R2,000.00 for communication and R2,000.00 for numeracy). If the learner commences at AET level one on both programmes and advances through levels one to four, the employer would have received R16,000.00 per learner, which would usually cover the cost of the training service provider. ${ }^{22}$ Artisan funding may be R30,000 per apprenticeship per year and the programme would usually be three years totalling R90,000.00. As indicated above, the Learnership is the main vehicle of implementation and recipient of discretionary grants, the following section expands upon this type of intervention, the funding and the contractual arrangements.

\footnotetext{
${ }^{18}$ National Integrated Human Resource Development Plan 2014-2018, (Pretoria: Government Printer 2014).

${ }^{19}$ DHET, National Skills Development Strategy III, (Pretoria: Government Printer 2011). Previous strategies: NSDS I (2000-2005) and NSDS II (2006-2010).

${ }^{20}$ RSA, The Skills Development Act 97 of 1998. Section 10A.

${ }^{21}$ Examples of SETA. Available at websites

http://www.merseta.org.za/LeviesandGrants.aspx;http://www.foodbev.co.za/grants/; http://www.mict.org.za/inner.aspx?section=5\&page=46 (last visited July 31, 2015).

${ }^{22}$ Depending upon company and employee negotiations, the training may be in either the personal time of the employee, paid time of the employer, or a combination of both. The employer funds the cost of registering the company as an examination centre and pays the cost of the examination costs. Pre-placement assessments may also sometimes be funded by discretionary grant funding.
} 


\section{LEARNERSHIP FUNDING}

The concept of a Learnership was specifically created by the SDA and consists of a structured learning component including theoretical knowledge, and a structured practical work experience component, for a specified duration. Each Learnership leads to a formal occupational qualification or part-qualification registered by the QCTO with the South African Qualifications Authority (SAQA) on the National Qualifications Framework (NQF). ${ }^{23}$ From the 2008 SDA amendments, an apprenticeship is included in the definition of a Learnership. The advantage of this inclusion will become apparent in the following paragraph as the taxation benefits of Learnerships are explained. Each learner on a Learnership enters into a Learnership agreement, which is administered by the SETA but is concluded between: the learner, an employer, and the training service provider (TSP) - a tripartite agreement. Consisting of a structured learning component and a structured work experience component, the learner progress is monitored by formative and summative assessments conducted by the TSP. Concurrent with the duration of the Learnership, the learner requires an employment contract with the employer. Minimum rates of pay are specified by the Learnership Sectoral Determination 5: Learnerships. ${ }^{24}$ A description of the financial implications for employers implementing Learnerships is required before exploring further the nature of the employment contract.

Unfunded Learnerships: Employers who are unable to obtain discretionary grant funding from the SETA with which they are registered, may go ahead and conclude agreements with learners and a TSP to provide "unfunded" Learnerships. The benefit to the employer is that, the financial costs incurred in implementation may be included in the assessment of the Skills Development element of the Broad-based Black Economic Empowerment (B-BBEE) scorecard. ${ }^{25}$ In addition, the employer will be able to benefit from the Learner Allowance, which is a reduction of taxable

\footnotetext{
${ }^{23}$ RSA, The Skills Development Act 97 of 1998. Sections 16-19 on Learnerships, and s26F-26J on the QCTO; RSA, National Qualifications Framework Act 67 of 2008, GoN 167 (Pretoria: GG No. 31909 2008). Sections 4-7 on the NQF, s10-23 on SAQA, and s26-27 on QCTO.

${ }^{24}$ Sectoral Determination 5: Learnerships, 432 GN 519 (Pretoria: GG No. 22370 2001). Minimum rates of pay are determined by the NQF level of the qualification, and are updated annually.

${ }^{25}$ RSA, Broad-Based Black Economic Empowerment Act 53 of 2003. "The fundamental objective of the Act is to advance economic transformation and enhance the economic participation of black people in the South African economy.” Available at https://www.thedti.gov.za/economic_empowerment/bee.jsp (last visited July 30, 2015). The relevance of the B-BBEE Act is that, enterprises are categorised by size and scored according to elements identified as relevant to economic transformation. For enterprises wishing to obtain business from the state via tenders, the outcome of the scoring exercise is critical.
} 


\section{SOUTH AFRICAN LABOUR LAW AMENDMENTS 971}

income by R30,000 per learner at commencement of the Learnership, and by a further R30,000 per learner at the conclusion of the programmeusually in the following or successive tax years (Increased to R50,000 per learner per commencement and R50,000 upon conclusion for registered disabled learners). Unusually for the South African Revenue Service (SARS), "double dipping" is also available to employers, if they contract with previously unemployed young persons ${ }^{26}$ and meet the requirements, they may also benefit from the Employment Tax Incentive (ETI), which supports the employment of previously unemployed persons and provides a further reduction of taxation payable, in the present period and may be accumulated against a future taxation liability. ${ }^{27}$

Discretionary Grant Funded Learnerships: In the event that, the SETA approves discretionary grant funding, the employer receives a discretionary grant payment of approximately R20,000 per learner per year-in addition to: the reduction in taxation, the B-BBEE scorecard calculation, and the ETI tax reduction as explained above. From this description, it is suggested that, there is considerable financial benefit to the employer in implementing Learnerships. The following section will examine the implementation of Learnerships at the workplace, and the confusion arising from the two forms of employment contractual arrangements.

\section{LEARNERSHIPS AND TWO FORMS OF EMPLOYMENT CONTRACT}

As indicated above, the acquisition of an occupational qualification via a Learnership requires two contracts, namely: the tripartite agreement with an employer and a TSP, and an employment contract with the employer. The person entering the Learnership may be an existing employee with a contract, or a previously unemployed person, who then concludes an employment contract for the duration of the Learnership. These learners are referred to colloquially - and for the remainder of this paper-as 18(1) or 18(2) learners. ${ }^{28}$ The tripartite agreement may not be terminated prior to agreed termination date unless: the learner achieves the desired competence earlier than the set date, the administrating SETA approves, or the learner is: "fairly dismissed for a reason related to conduct or capacity" ${ }^{29}$ This last clause (section 17(4) (c) would appear to refer to a dismissal in terms of the

\footnotetext{
${ }^{26}$ The distinction between learners in employment before contracting on a learnership and those unemployed will be covered in the following section on Learnerships and forms of the employment contract.

${ }^{27}$ RSA, Employment Tax Incentive Act of 2013.

${ }^{28}$ RSA, The Skills Development Act 97 of 1998. Sections 18(1) and 18(2).

${ }^{29}$ RSA, The Skills Development Act 97 of 1998. Section 17(4) (c).
} 
employment contract. It follows therefore that, this would be covered by the standards of the LRA. This conclusion is supported: firstly, by section 18(5) of the SDA, which set outs that, the contract of employment may be terminated in terms of section 17(4) and secondly, by section 19(6) of the SDA, which makes reference to the "lawfulness" and "fairness" of a dismissal related to conduct or capacity including a contract contemplated in section 18(2). Section 18(6) then confirms that, the contract of employment of a learner terminates at the end of the specified learnership duration, unless the employment relationship already existed, in which case the employee rights are unaltered by the conclusion of the learnership. ${ }^{30}$

\section{THE SOURCE OF TwO FormS OF EMPLOYMENT CONTRACT}

The first implication of the Learnership agreement arises from the termination conditions. Whether the learner was previously employed or newly employed, in both cases, the employment contract may not be terminated "before the expiry of the period of duration specified in the Learnership agreement unless the learnership agreement is terminated in terms of section 17(4)" (of the SDA), that is: conduct or capacity. Therefore it may be interpreted that, neither the tripartite Learnership agreement nor the employment contract may be terminated for operational requirements. Unfortunately for the purposes of this paper, there does not appear to have been any legal challenge to this interpretation.

However, a number of other circumstances have given rise to confusion within the ranks of human resource, payroll and training practitioners. Terms and conditions of the employment contract for the 18(2) learners are governed by the Sectoral Determination 5: Learnership Sector. ${ }^{31}$ Although the Department of Labour, which issues the determination uses the wording "employment contract" and "employment" both in the determination and on the website, and SARS documents also use that wording, there appears to be a widespread view that the 18(2) learners are not "employees". The next section aims to contrast legal wording in relevant documents with what may be termed the "prevailing view" of practitioners.

\footnotetext{
${ }^{30}$ RSA, The Skills Development Act 97 of 1998. Section 18(6).

${ }^{31}$ Sectoral Determination 5: Learnerships, 432 GN 519 (Pretoria: GG 22370 2001). The determination essentially mirrors the standard clauses of the BCEA, and publishes updates to the stipend rates, which are based upon the NQF level of the Learnership. The current document provides rates until March 31, 2016. Available at http://www.labour.gov.za/DOL/downloads/legislation/sectoral-determinations/basic-conditions-ofemployment/learnershipalowances015.pdf (last visited July 31, 2015).
} 


\section{SOUTH AFRICAN LABOUR LAW AMENDMENTS 973}

\section{DOCUMENTARY EVIDENCE SUPPORTING THE 18(2) EMPLOYMENT CONTRACT}

A central definition of labour and employment law is that of the "employee". Notable for the following discussion, the LRA defines "employment law" as including: the Unemployment Insurance Act (UIF Act) ${ }^{32}$ the EEA and the SDA. ${ }^{33}$ Following the work of Simon Deakin on the evolution of the contract of employment in Britain, Le Roux has noted that, South Africa has reached a relative state of unification of the employment contract. ${ }^{34}$ One of the aspects Le Roux examines is the "control test", in terms of which the 18(2) learners would certainly comply. The control test is also one of the elements used in the NEDLAC Code of Good Practice. ${ }^{35}$ Under the ETI, the SARS would include 18(2) learners for the purpose of employers qualifying for that taxation incentive. ${ }^{36}$ The SARS Interpretation Note on the Additional Deduction for Learnership Agreements ${ }^{37}$ refers to a "registered learnership agreement,” and specifies that: “... any period during which - a learnership agreement is not registered, or a learner is not in employment, will not qualify for the annual allowance.” ${ }^{38}$ This wording appears to contemplate "employment".

Focusing on definitions, the LRA definition of employee states:

(a) “... any person ... who works for another person”, and also of relevance;

(b) “... any other person who in any manner assists in carrying on or conducting the business of an employer". ${ }^{39}$

The Sectoral Determination then defines "work" as:

“... 'work' includes any time that, the learner is required to spend in study periods or theoretical learning sessions with the training provider in terms of the learnership agreement.”

The application of the determination applies to:

“(a) the employment of a learner-

(i) who has concluded a learnership agreement ... and;

\footnotetext{
${ }^{32}$ RSA, Unemployment Insurance Act 63 of 2001.

${ }^{33}$ An identical definition exists in the BCEA s1.

${ }^{34}$ Le Roux, The Evolution of the Contract of Employment in South Africa, 39 INDUSTRIAL LAW JOURNAL (2010).

${ }^{35}$ NEDLAC, Code of Good Practice: Who is an Employee? (Pretoria: NEDLAC 2006).

${ }^{36}$ RSA, Employment Tax Incentive Act 26 of 2013.

${ }^{37}$ RSA, Income Tax Act 58 of 1962 Interpretation Note, 20(4) (2011).

${ }^{38}$ RSA, Income Tax Act 58 of 1962 Interpretation Note, 20(4) 5-6.

${ }^{39}$ RSA, The Labour Relations Act 66 of 1995. Section 213.
} 
(ii) who was not in the employment of the employer party to the learnership agreement when the agreement was concluded.” Finally:

"This determination forms part of the contract of employment of any learner employed in terms of section 18(2) of the Act."40

Finally, the Department of Labour has tabled an amendment to the Unemployment Insurance Act to include: “... learners who are undergoing learnership training..."41

\section{EXAMPLES OF LEARNERSHIPS IN PRACTICE}

From the section above, it would appear that, the Department of Labour intention was for an employment relationship to be established for the 18(2) learners. What would be the motivation for excluding the learner from an employment relationship? If it were considered that, the majority of time would be spent in a classroom or training venue, then it may be argued as appropriate given that, the employer is not gaining the benefit of their work. On the contrary, in practice especially for the lower level Learnerships the formal knowledge component of the Learnership comprises approximately 30\%. The employee is working at an occupation for the employer for the majority of the contract period.

One common example is that of call centres, where a voice recording warns callers that, the consultant is operating "under supervision"; the "consultant" is on a Learnership but fulfilling all the requirements of the occupational role-albeit lacking in experience. A second example is the articled clerk in accounting firms: here the years of being "articled" have been registered as a Learnership - in this case at a very senior postgraduate level, and for a number of years. In the past, the articled clerk was always regarded as an "employee” for the duration of their articles. Whether they received tenure thereafter was generally decided based upon performance and suitability. This is comparable to the three year apprenticeship, where the apprentice was employed for the duration of the apprenticeship, and completes work under the supervision of master artisan at an apprenticeship remuneration rate. The employment contract terminates once the trade test is passed and the employer decides whether an additional permanent qualified artisan is required. The Learnership is specifically for an occupational qualification, which may only be acquired with work-based experience, the

\footnotetext{
${ }^{40}$ Sectoral Determination 5: Learnerships, 432 2001-GG22370 GN No. 519. Sections 1, 2(1)(a)(i)-(ii), and 2(a).

${ }^{41}$ RSA, Unemployment Insurance Amendment Bill, B25 OF 2015 PuBlication of EXPLANATORY SUMMARY. GG39273 GN No. 967 of October 8, 2015.
} 


\section{SOUTH AFRICAN LABOUR LAW AMENDMENTS 975}

question may therefore be posed: what is the source of reluctance to accept the learners on 18(2) Learnership contracts as a fixed-term employment contract, and what are some of the implications?

In the event that, the Learnership qualification is acquired and the "learner" is employed permanently, the Learnership duration, which as indicated above may be a number of years may well not be credited. This may prejudice any long-service benefits that the employer may offer. In addition, it has become apparent that, employers may place learners on successive Learnership agreements. This raises the question of the employer motivation to avoid an employment relationship. In contrast to the section above, where documentary evidence appears to imply an employment relationship, a number of instances are advanced for a contrary interpretation.

\section{COUNTER ARguments to AN 18(2) EMPLOYEe StATUS}

The payments to learners are not included in the calculation of SDL payments to SARS. ${ }^{42}$ No deduction is made currently from the learners for UIF $^{43}$ and they do not qualify to draw unemployment insurance. The learners receive a stipend set by the Sectoral Determination on Learnerships. ${ }^{44}$ The learners do not receive the same conditions as other employees within the company, for example: such as medical aid scheme contributions, or pension or provident fund scheme contributions. ${ }^{45}$ The BBBEE scorecard rewards companies for "absorption" of learners into the company for "formal permanent or long-term contract" employment, the implication being that, they are not employees. ${ }^{46}$ It would appear from this list that, there are counter arguments in that differing conditions of employment do not necessarily remove the employment status of the 18(2) learner. However, the points do highlight the apparent incentive of South African employers to reduce complement numbers wherever possible. The possible rationale for that stance is set out below with discussion of the implications of some of the labour law amendments.

\section{EMPLOYER RESISTANCE TO A FORMAL EMPLOYMENT RELATIONSHIP}

The criticality of workplace-based experience for the acquisition of

\footnotetext{
${ }^{42}$ RSA, Skills Development Levies Act 9 of 1999. Section 3(5)(d).

${ }^{43}$ RSA, Unemployment Insurance Act 63 of 2001.

${ }^{44}$ Sectoral Determination 5: Learnerships, 432 (2001).

${ }^{45}$ Personal correspondence. July 31, 2015.

${ }^{46}$ Broad-Based Black Economic Empowerment Act (53/2013): Codes of Good Practice, DTI 91 (2013).
} 
occupational qualifications has been made clear. Access to workplace-based learning and experience is essential for achieving the occupational skills and qualifications that provide access to permanent employment for young people. Workplace-based learning is defined as: "The exposure and interactions required to practice the integration of knowledge, skills and attitudes required in the workplace. ${ }^{, 47}$ This follows the purpose and intent of both the SDA and the EEA. What then is the source of employer reluctance to increase employment?

South African labour law is firmly grounded in numbers. The SDLA targets a payroll of above R500,000 per annum, which in practice across a number of sectors represents 10-12 employees. The dti has established definitions of small medium and micro enterprises and the latest B-BBEE Exempt Micro Enterprise level is R10 million annual turnover. The LRA excludes employees earning above the BCEA earnings threshold from cover, and exempts employers employing less than 10 employees or fewer than 50 where the business has been in operation less than 2 years from application of requirements for part-time employees. ${ }^{48}$ The EEA has established "designated employers" at more than 50 employees ${ }^{49}$ and until the recent amendments only companies with more than 150 employees required annual reporting-now all designated companies are required to report annually. ${ }^{50}$

The implementation both of skills development and employment equity requires a consultative committee. The EEA has always required consultation with a committee representative of all employees for all designated employers, including trade union representation. ${ }^{51}$ Initially skills development included a similar requirement, but the requirement fell away with amendments to Regulations and re-surfaced with the latest Grant Regulations now requiring companies of over 50 employees to have evidence of consultation by signature on plans and reports submitted-also including union representation. ${ }^{52}$ The initial removal may well have resulted from early signs by union representatives of refusal to sign Workplace Skills Plans. However, employers have resisted any attempts to move skills development into an industrial relations arena. One of the issues identified

\footnotetext{
${ }^{47}$ Available at http://hr.saqa.co.za/glossary/search_widget.php?id=139 (last visited July 30, 2015).

${ }^{48}$ RSA, The Labour Relations Act 66 of 1995. Section 198.

${ }^{49}$ Available at http://www.dti.gov.za/economic_empowerment/bee.jsp (last visited July 30, 2015).

${ }^{50}$ Employers who have less than 50 employees but have a turnover above the Schedule 4 level for their sector are also “designated” employers. RSA, Skills Development Levies Act 9 of 1999. Section 1 Definitions.

${ }^{51}$ RSA, Employment Equity Act 55 of 1998. Section 16.

${ }^{52}$ The SETA Grant Regulations regarding Monies Received by SETA \& Related Matters in of 2012and Amendment Notice to Gon R.990 Published in GG No.35940 of December 3, 2012 in of 2013July 15, 2013.
} 


\section{SOUTH AFRICAN LABOUR LAW AMENDMENTS 977}

by Godfrey, et al. ${ }^{53}$ is that, with the implementation of the skills development SETA landscape and the removal of skills development from the bargaining council agenda, the potential for bargaining skills acquisition and productivity improvements against increased wages has been entirely compromised. It is ironic then that, equal pay for work of equal value has now landed firmly on the table as a result of the Employment Equity amendments, which will be discussed in the following section.

\section{EMPLOYMENT EQUITY ACT AND UNFAIR DISCRIMINATION}

By targeting adults in the workplace skills development has been seen as a key policy instrument of redress and a supporting instrument for the removal of barriers to appointment and advancement and enhancing effective implementation of the objectives of the Employment Equity Act. Section 6(1) on unfair discrimination via: "any employment policy or practice”, includes training and development. An aspect of Learnership implementation that, appears not to have reached the Commission for Conciliation Mediation and Arbitration (CCMA) is the plight of female employees who fall pregnant shortly after commencing their Learnership. In practice in most companies, because of the extremely programmatic nature of Learnerships, with modules being assessed and completion dates set, it is practically impossible to accommodate maternity leave. Unless handled sensitively this may lead to unfair discrimination on a listed ground. Larger organisations with repeated Learnership programmes provide the chance to join a subsequent programme. It is interesting to consider what aspects of skills development such as this may lead to an allegation of unfair discrimination, the most likely would be of exclusion from a desired programme.

\section{EMPLOYMENT EQUITY REGULATIONS}

Possibly the main driver of workplace equality will be the equal pay for work of equal value amendments. The Minister of Labour issued the Employment Equity Regulations 2014, which contain guidance on the establishment of the criterion, methodology, and means of assessing work of equal value in terms of s6(4). ${ }^{54}$ Equal work is defined in the Regulations as including: “... work that is the same, substantially the same or of the same

\footnotetext{
${ }^{53}$ Godfrey, The State of Collective Bargaining in South Africa, AN EMPIRICAL AND CONCEPTUAL Study of Collective Bargaining 143 (Cape Town: Development Policy Research Unit 2007).

${ }^{54}$ Employment Equity Regulations 2014, GG37873 GN No R595 (2014).
} 
value as other work". An argument that may be made by those on a Learnership compared to the permanent workforce-doing same or "substantially the same" work. The Regulations indicate that an exception to different pay would be: “... where an individual is employed temporarily in a position for purposes of gaining experience or training and as a result receives different remuneration or enjoys different terms and conditions of employment". This would be consistent with the different terms and conditions experienced by the 18(2) learners. ${ }^{55}$ However, at some point, this may be challenged. In unskilled and semi-skilled positions, where the work consists of relatively simple repetitive tasks of limited variety and duration, such as fish filleting for example, it will be difficult to argue what amount of additional skill is gained from a few more months-or years-experience. Analysis to ascertain equal work requires an analysis of the individual jobs: the responsibility in terms of people, finances and material, qualifications and skills, and the effort involved whether physical, mental or emotional. ${ }^{56}$

\section{EMPLOYMENT EQUiTy CODE OF GOOD PRACTICE}

The requirements above centre on the nature of the job, the work to be done and the nature of the demands. In contrast Code of Good Practice on Equal Pay/Remuneration ${ }^{57}$ moves the focus to the remuneration received by the incumbents. The Code aims to set out guidelines on how the assessment of equal pay is to be achieved, namely through: “...human resources policies, practices and job evaluation processes." ${ }^{\text {}}$ The document identifies past discriminatory practices, particularly those based upon race and gender. The codes also include again the analysis of the requirements for a job, that is: "The skills, qualifications, including prior learning and experience required to perform the work, whether formal or informal. This includes knowledge and skills that are required for a job. What is important is not how these were acquired but rather that their content corresponds to the requirements of the job being evaluated. Qualifications and skills can be acquired in various ways including academic or vocational training certified by a diploma, paid work experience in the labour market, formal and informal training in the workplace and volunteer work." ${ }^{59}$ As mentioned previously, this description sits squarely in the domain of skills development

\footnotetext{
${ }^{55}$ Employment Equity Regulations 2014, R595 8 (2014).

${ }^{56}$ Employment Equity Regulations 2014, R595 7 (2014).

${ }^{57}$ Code of Good Practice on Equal Pay/Remuneration for Work of Equal Value, GG38837 GoN448 (2015).

${ }^{58}$ Code of Good Practice on Equal Pay/Remuneration for Work of Equal Value, GoN448 8 (2015).

${ }^{59}$ Code of Good Practice on Equal Pay/Remuneration for Work of Equal Value, GoN448 11 (2015).
} 


\section{SOUTH AFRICAN LABOUR LAW AMENDMENTS 979}

and occupational qualifications, and adds the Recognition of Prior Learning. This is an area that has been the despair of many skills development practitioners for the lack of progress. ${ }^{60}$

From an industrial relations perspective, unions traditionally seen longservice as beneficial and worthy of additional financial reward, with many companies giving long service awards and long-service payments. In contrast, from a human resource management perspective, this has negative implications as a static workforce is seen as an obstacle to the implementation of employment equity principles. Particularly older longserving employees may be reluctant to participate in literacy and numeracy programmes, which given the increased technology requirements hampers productivity improvements as well as limiting promotion prospects. A potentially powerful aspect of this Code of Good Practice is to achieve an integration of human resource management practices, with employment equity and skills development implementation.

\section{EMPLOYMENT EQUITY COMPLIANCE}

In an assessment of compliance with the requirements of the EEA, ${ }^{61}$ the employer would be required to demonstrate: measures to identify and remove barriers to advancement, measures to ensure representation of diverse suitably qualified people, and to implement retention measures to retain those developed from designated groups. Whether the individual is "suitably qualified" may be determined by one or any appropriate combination of the following factors: formal qualifications, prior learning, relevant experience, or the capacity to acquire the necessary skills and ability within a reasonable time, this last element would suggest psychometric testing of learning potential. One word that is not used in this context is competence, and this may be an instance where the terminology and processes of skills development would benefit the implementation of the intentions of this section, applied competence is defined as: "A learner's ability to integrate concepts, ideas and actions in authentic, real-life contexts which is expressed as practical, foundational and reflexive competence". Assessment is defined as: "A structured process for gathering evidence and making judgments about an individual's performance in relation to registered national unit standards and qualifications." ${ }^{62}$ Suitably qualified

\footnotetext{
${ }^{60}$ A substantial number of policy documents and conference presentations on RPL are available on the SAQA site. Available at http://www.saqa.org.za/list.php?e=RPL (last visited July 31, 2015).

${ }^{61}$ RSA, Employment Equity Act 55 of 1998. Section 15.

${ }^{62}$ SAQA, Guidelines for Integrated Assessment, i (Pretoria: SAQA 2005).
} 
implies job analysis and appropriate occupational training and development. As described in the discretionary grant section, the range of PIVOTAL programmes are ideally suited to meet these requirements.

Finally, the EEA Code of Good Practice a number of additional documents, which should be read in conjunction including the ILO Remuneration Convention 100 of $1951,{ }^{63}$ and of central importance the Integration of EE into HR policies and practices. ${ }^{64}$

\section{PAyment TO PROCURE TRAINING}

Other than the Sectoral Determination on Learnerships there is minimal impact of the BCEA on skills development. However, section 33 A (1) (a) prohibits the acceptance by an employer of any payment in exchange for a job. It is unfortunate that, this section did not also include (as the following section does) the words: "any business nominated by the employer" as work-seekers have been lured into "training programmes ostensibly in the hope of gaining employment. ${ }^{65}$ The relationship between training and employment is explored further in the following section.

\section{TEMPORARY EMPLOYMENT SERVICES AND LEARNERSHIPS}

The intentions of the amendments to the LRA ${ }^{66}$ are clearly spelt out and have been the subject of debate for a period of years by academics, development organisations, and particularly by the parties at NEDLAC, ${ }^{67}$ namely: to reduce the growth of atypical forms of employment, and to limit the scope of tri-partite relationships, that is the TES or labour brokers. Apart from various changes to collective bargaining landscape, possibly the most important aspect of the LRA amendments for skills development is the clause "deeming" persons placed by a TES with a client for more than three months, to be "deemed" as the employee of the client. ${ }^{68}$ Two recent cases confirm this interpretation. ${ }^{69}$

\footnotetext{
${ }^{63}$ Available at

http://www.ilo.org/dyn/normlex/en/f?p=NORMLEXPUB:12100:0::NO::P12100_ILO_CODE:C100 (last visited July 31, 2015).

${ }^{64}$ Integration of EE into Human Resource Policies and Practices, GG27866 GeNN 1358 (2005).

${ }^{65}$ RSA, Basic Conditions of Employment Act 75 of 1997, s33A(1)(a).

${ }^{66}$ RSA, The Labour Relations Act 66 of 1995. The amendments came into effect January 1, 2015 and apply to workers earning below the BCEA prescribed earning threshold—currently R205,433.30 per annum.

${ }^{67}$ The author is indebted to John Botha and to Johnny Goldberg for the information provided on TES.

${ }^{68}$ RSA, The Labour Relations Act 66 of 1995. Section 198.

${ }^{69}$ Assign Services (Pty) Ltd and Krost Shelving \& Racking (Pty) Ltd and NUMSA 2015 ECEL165215, and Refilwe Esau Mphirime and Value Logistics Ltd/BDM Staffing (Pty) Ltd 2015 FSRFBC34922.
} 


\section{SOUTH AFRICAN LABOUR LAW AMENDMENTS 981}

Implications for the funding of Learnerships through discretionary grants however, is not clear. ${ }^{70}$ The TES would be registered with the Services SETA and the discretionary grant funding to cover Learnerships would be from that source. If the employee is deemed the employee of the client, will the SETA with which the client is registered, then take over Learnerships - and discretionary funding? Given the process for application and the time-consuming bureaucracy to contract the learners, this would appear unlikely. If the TES continues to pay the employee as an outsourced payroll service, and to pay the SDL, then the discretionary grant could still be accessed from the TES registered SETA. However, SARS provides an exemption annually in respect of TES employee tax, it is unclear whether that would continue. ${ }^{71}$

The key question regarding skills development implications of the TES amendments, is the extent to which the TES have been placing Learnerships as part of their placements with clients. The statistics are not readily accessible from the Services SETA Annual Reports. However, Bhorat, et al. ${ }^{72}$ have highlighted the substantial extent to which the total level of TES placements has fallen subsequent to the LRA amendments. The industry has in the past claimed to be a creator of jobs, contrary to the very early image of TES taking over the employment of previously employed persons on reduced employment conditions. If the "deemed" employees on a Learnership were to continue it would require an amendment to the Learnership agreement and potentially an updated employment contract, and the learner and the SETA would be required to approve the documentary changes. $^{73}$

An extremely positive aspect in support of skills development implementation is the requirement that part-time employees should receive the same access to training and development as full-time employees. ${ }^{74}$ In protection against the misuse of fixed term contracts, one of the accepted reasons for such a contract is for employing a student or recent graduate (which would be for internship also covered by SETA discretionary grant funding) and "for the purpose of being trained".

\footnotetext{
${ }^{70}$ Attempts by the author to obtain official SETA comment were unsuccessful.

${ }^{71}$ SARS, Guide for Employers in Respect of Employees' Tax (2016) Tax Year, (PAYE-GEN-01-G10: SARS 2015).

${ }^{72}$ Bhorat, Magadla \& Steenkamp, Employment Effects in the Temporary Employment Services TES Sector: Post-Regulatory Amendment Effects, (2015); Bhorat, Cassim \& Yu, Temporary Employment Services in South Africa: Assessing the Industry's Economic Contribution, (2014).

${ }^{73}$ RSA, The Skills Development Act 97 of 1998. Section 17(5).

${ }^{74}$ RSA, Employment Equity Act 55 of 1998. Section 6; RSA, The Labour Relations Act 66 of 1995. Section 198.

${ }^{75}$ RSA, The Labour Relations Act 66 of 1995. Section 198B(4).
} 


\section{CONCLUSION}

The South African skills development landscape is characterised by a plethora of acronyms, complex pedagogic and andragogic learning theory, and bureaucratic SETA administration. At the coalface however are the adult learners grappling with literacy and numeracy, or the development of technical artisan skills, or seeking an occupational qualification via the Learnership route. This paper has endeavoured to highlight how the format of workplace-based learning interacts not only with mainstream labour law, but also unemployment protection and taxation. Within this context, it is easy to overlook the many industrial relations implications of the implementation of learnerships, and issues as central and familiar to labour law practitioners as the definition of "an employee". Ultimately all aspects of these activities rest within the human resource management purview and the management of people at work.

Therefore, the latest amendments to the EEA, with the 2014 Regulations and 2015 Code of Good Practice are seen as an enormously positive step for the implementation not only of employment equity, but also for skills development. It is unsurprising that, the majority of the observations of this paper centred on that area. The pulling together of the human resource management aspects of the implementation of employment equity and skills development is seen as positive. The challenges are to redress the legacy of discrimination in education and the workplace within a developing country context.

The plea is for "joined up" policy and strategy, interdisciplinary coherence of mutually supportive definitions, policy that further encourages the employment of youth, and clarity and certainty particularly for the 18(2) learners, their employers and the skills development practitioners. 


\section{SOUTH AFRICAN LABOUR LAW AMENDMENTS 983}

\section{ACRONYMS}

$\begin{array}{ll}\text { ABET } & \text { Adult Basic Education and Training } \\ \text { AET } & \text { Adult Education and Training } \\ \text { BCEA } & \text { Basic Conditions of Employment Act } \\ \text { DHET } & \text { Department Higher Education and Training } \\ \text { DoL } & \text { Department of Labour } \\ \text { dti } & \text { Department of Trade and Industry } \\ \text { EEA } & \text { Employment Equity Act } \\ \text { ETI } & \text { Employment Tax Incentive } \\ \text { FET } & \text { Further Education and Training } \\ \text { LRA } & \text { Labour Relations Act } \\ \text { NASCA } & \text { National Adult Standard Certificate } \\ \text { NHRDSSA } & \text { National Human Resource Development Strategy of South Africa } \\ \text { NIHRDS } & \text { National Human Resource Development Strategy } \\ \text { NQF } & \text { National Qualifications Framework } \\ \text { NSDS } & \text { National Skills Development Strategy } \\ \text { NSF } & \text { National Skills Fund } \\ \text { PIVOTAL } & \text { Professional Vocational Technical and Academic } \\ \text { PSET } & \text { Post-school Education and Training } \\ \text { QCTO } & \text { Quality Council for Trades and Occupations } \\ \text { QLFS } & \text { Quarterly Labour Force Survey } \\ \text { RSA } & \text { Republic of South Africa } \\ \text { SAQA } & \text { South African Qualifications Authority } \\ \text { SARS } & \text { South African Revenue Services } \\ \text { SDA } & \text { Skills Development Act } \\ \text { SDF } & \text { Skills Development Facilitator } \\ \text { SDL } & \text { Skills Development Levy } \\ \text { SETA } & \text { Sector Education and Training Authority } \\ \text { TES } & \text { Temporary Employment Service } \\ \text { TVET } & \text { Technical Vocational Education and Training } \\ \text { WBL } & \text { Work-based learning } \\ \text { WIL } & \text { Work-integrated learning } \\ & \end{array}$

